\title{
The Effect of Chemical Defenses on the Density of Insect Herbivores Between High, Medium and Coastal Elevations of Al Jebel Al
}

Akhdar

\author{
Abdlrahman Y Al Faituri \\ Plant protection, Omar Al-Mukhtar University Al-Bayda-Libya
}

Received: 18 February 2019/ Accepted: 30 June 2019

Doi: https://doi.org/10.54172/mjsc.v34i2.83

\begin{abstract}
The study area is dominated by Juniperus sp and Pistacia sp, the two species, the study aimed to investigate the effect of chemical defences on the density of insect herbivores, and the results showed that the two species differed very much in their levels of phenols. Pistacia had the highest concentrations (overall $2308 \pm 43 \mathrm{ppm}, \mathrm{n}=45$ ), with Juniperus quite a bit lower $(1516 \pm 43, \mathrm{n}=45)$. Overall levels of phenols were highest in plants from the middle and lowest in those from the bottom elevation level. This effect of the level was significant, showing that the two species showed the same pattern with elevation. There were substantial differences among plots within levels. This has affected the numerical density of the insects, where it was observed that their density on the tested Juniperus sp shrubs was more than the intensity on the tested Pistacia sp shrubs.
\end{abstract}

Keywords: Phenolic defences; Juniperus and Pistacia; insect Herbivores; Al Jabal Al Akhdar, Libya

\section{INTRODUCTION}

Plants in natural populations are frequently attacked by a huge number of natural enemies, comprising both pathogens and herbivores at all periods of their life cycles. Pest stress can be devastating, as demonstrated by the epidemics of insects and diseases in farmed crops, and in the success of weed control by biological control (Levin, 1976). Outbreaks or episodes of intensive herbivory may lead straight to the local extinction of a plant species, or weaken plants and make them vulnerable to subsequent ecological pressures (Levin, 1976). The lowering of photosynthetic ability due to disease or partial defoliation reduces resistance to biotic stresses or infection by other pests, and decreases competitive capacity (Levin, 1976). From a user perspective, varied stands lead to mixed resources within which herbivores choose their favored individuals. It is well recognized that the amount of herbivory is strongly determined by leaf chemical and physical characters counting how they differ within a given host species with rising plant diversity, competition or facilitation among species could activate changes in plant nutritional quality or the creation of secondary metabolites (Muiruri et al., 2019).

Mediterranean climate regions experience reducing rainfall with decreasing latitude towards the equator, and there is a gradual change in vegetation toward plants that are adapted to semi-arid and desert conditions (Dallman, 1998). The local vegetation of the

*Corresponding Author: Abd Rahman Y. El-Fitori insecta2005@yahoo.com Faculty of Agriculture, University of Omar AL-Mukhtar, Al-Bayda, Libya. 
Mediterranean lands is adapted to survive long hot summer droughts and prolonged wet periods in winter (Martinez, 2002). The amount of energy allocated by Mediterranean plants to growth and maintenance is comparatively high-low resource accessibility may either be a cue for a plastic response that leads to, or a selection pressure for the evolution of, a greater investment in protection against biotic agents, that is shown by greater investment in defensive chemicals such as phenols, alkaloids, etc.(Dallman, 1998). Lack of water might also be involved; perhaps by restricting growth rate, this might also lead to the accumulation of defense compounds for greater resistance against natural enemies. Therefore, the cost of producing chemical defenses might be predicted to be higher in Mediterranean species than in those living in more favorable biomes. Mediterranean habitats vary in several characteristics; if these include nutrient and water availability, we might predict differences in the chemical defenses of Mediterranean plant species. Thus, plants at different elevations should invest different amounts in defense because of the availability of water and nutrients (Martinez, 2002).

Mediterranean plants have experienced high levels of herbivory by wild and domesticated ungulates over thousands of years (Massei, Hartley, \& Bacon, 2000). We might expect, therefore, the existence of evolved interactions with mammals, but actually, very little attention has been paid to plant-mammal interactions in Mediterranean ecosystems. Phenolic concentrations were consistently higher in winter than in spring, and in new rather than old leaves, just when browsing is more probable (Glyphis \& Puttick, 1988; Massei et al., 2000). These compounds reduce the palatability of plants to mammalian herbivores, but there is no evidence that they are induced by browsing (Massei et al., 2000; Rohner \& Ward, 1997), although regrowth foliage following browsing may have decreased levels of phenolics in other ecosystems(Bryant, Heitkonig, Kuropat, \& Owen-Smith, 1991; Bryant, Reichardt, \& Clausen, 1992). (Glyphis \& Puttick, 1988) showed that levels of phenolic compounds in shrub leaves are higher in winter than spring, and in new than older leaves, in only half of the species they checked.

The current study was carried out in the Al Jabal Al Akhdar region of Libya that consists of a high density of evergreen species of shrub and trees. We analysed variation among individual plants, among plots, and among elevations in the phenol levels of the two dominant species, that there will be differences in phenol concentrations in Juniperus and Pistacia within elevation. After testing this prediction, I will go on to test the impact of that plant chemistry (in the form of tannin levels) have on the density and distribution of insect herbivores on Pistacia atlantica and Juniperus phoenicea. Insects herbivory rates are affected by plant traits (such as levels of chemical defenses).

This research aims to study the effect of chemical defenses (phenols) on the types of insect herbivory among the top, middle and bottom elevations sampled in the Al Jabal Al Akhdar region of Libya.

\section{MATERIALS AND METHODS}

The study was carried out in the Al Jabal Al Akhdar in northeastern Libya $\left(32^{\circ} 49^{\prime} \mathrm{N}\right.$; $\left.21^{\circ} 51^{\prime} \mathrm{E}\right)$. The climate is Mediterranean: mean temperatures vary between $25^{\circ} \mathrm{C}$ in February and $33{ }^{\circ} \mathrm{C}$ in July, and rainfall ranges between 520 and $600 \mathrm{~mm}$ per year (Faituri, 2002). The study area is dominated by Juniperus phoenicea and Pistacia sp. plants of each species were selected randomly and marked permanently in each of the nine plots at three different elevations (bottom 0-200 m, middle 200$400 \mathrm{~m}$, and top 400-880 $\mathrm{m}$ above sea level). At each elevation, three plots were placed randomly that each was more than $1 \mathrm{~km}$ away from the others. Ten fresh leaves per shrub/tree were 
collected from each marked plant: Juniperus ( $n$ $=45)$ and Pistacia $(n=45)$. Leaves were ovendried at $60{ }^{\circ} \mathrm{C}$ for 48 hours, milled and analyzed at the Plant Protection Department at Omar Al Mukhtar University.

For collecting free-living insects, the methods used were sweep nets and beating. Collected specimens were killed by freezing, then pinned, labeled, and subsequently identified at the Natural History Museum in London. We selected elevations in a random order but were visited. The strategy was first to walk around the tree/shrub and observe what insects were present, and catching those which are reachable without disturbance. Then we worked through the foliage by hand, starting from the top, thoroughly and systematically turning over leaves and branches initially until the range had been fully appreciated, all insects were collected from each tree/shrub, and after that, we counted the number of each type. It took more than one day to sample five plants. Every individual insect was given an identification code that tracked when, where, and on which plant it was collected. Some individual insects were maintained alive to ascertain whether the species was a herbivore of Juniperus or Pistacia. We placed a single insect in a Petri dish with some cut pieces of uneaten leaf material and a wad of wet tissue. The insects were checked periodically, and after 48 hours, we noted which ones have or have not fed. All were then frozen and pinned. The distinction between true herbivores and other insects is made clear in the results section. The assessment of the numbers of various insect pest species was done by carefully examining the selected host plants, leaf by leaf, and turning of leaves as well to collect any insects from the under-surface of the leaves. The insect herbivores collected from each plot were identified, counted and recorded. This study focuses on the insect herbivores that feed on the leaves of Pistacia and Juniperus, and others that attack the trunk, if found. There are insect herbivores that were not studied for the lack of time, such as those that feed on seeds, fruits, roots or that live under the bark.
Leaf samples were analyzed for total phenolics measured by detecting phenolate ions. Tannic acid was used as a standard, and the extraction of dried leaf material was carried out using $50 \%$ aqueous methanol. Phenolic content was expressed as \% dry weight (calculated as mg tannic acid equivalents per mg dry leaf mass $\times$ 100). The Phenolic assay was conducted according to the Folin-Ciocalteau method (Waterman \& Mole, 1994). The protocol followed for this study was as follows: A standardized Phenolic solution was prepared with 10 $\pm 0.3 \mathrm{mg}$ tannic acid in $100 \mathrm{ml}$ water. The precise amount used was recorded for use in later calculations. A 'blank' $4.2 \mathrm{ml}$ cuvette was prepared with $3 \mathrm{ml}$ DI water. A series of cuvettes were prepared with 50-450 ml tannic acid solution in $50 \mathrm{ml}$ increments and made up to $3 \mathrm{ml}$ with DI water; and used to produce a standard line of tannic acid concentration by regression. For each sample to be analyzed, $15 \pm 0.3 \mathrm{mg}$ of ground leaf material was taken, and the precise amount used was recorded. Each sample was shaken with $10 \mathrm{ml}$ of $50 \%$ methanol solution and phenolics extracted by standing in a sealed boiling tube in a water bath at $80^{\circ} \mathrm{C}$ for 30 minutes. Samples were immediately transferred to centrifuge tubes and spun at $3000 \mathrm{rpm}$ for 15 mins, and $100 \mathrm{ml}$ of each sample was placed in two cuvettes. These were made up to $3 \mathrm{ml}$ with DI water and $0.25 \mathrm{ml}$ saturated $\mathrm{CaCO}_{3}$ solution and $0.25 \mathrm{ml}$ Folin-Ciocalteau reagents added to each cuvette. The cuvettes were covered in parafilm and mixed, then left to stand. After 1 $\mathrm{hr}$, the absorbance at $760 \mathrm{~nm}$ was measured for each cuvette against the blank prepared earlier. The mean value between the two replicates of each sample was taken. If the difference in absorbance between the two samples exceeded 0.05 , the entire run was repeated, although in practice the two values were usually very close. The percentage of dry mass phenolics (\%DM) in each sample were calculated by comparison with the standard line according to the formula:

$$
\% D M=\frac{T A}{W} \times\left[\frac{A 760-c}{m}\right]
$$


Where TA is the amount of tannic acid used in $\mathrm{mg}, \mathrm{W}$ is the initial sample mass in $\mathrm{mg}, \mathrm{A} 760$ is the mean absorbance for each sample, $\mathrm{m}$ and $\mathrm{c}$ are the gradients, and $\mathrm{y}$-intercept of the standard line. Standard lines were produced at the start and the end of each day to confirm the consistency of measurements. Results are presented here as the parts per million of leaf dry weight that is made up of phenolics (or, more strictly, tannic acid equivalents).

We analyzed the phenolic content in the two species using GLM implemented in SPSS16. The design of the analysis was species + level + plot $($ level $)+$ species*level. The data were not normal (Shapiro-Wilk $=0.955$, df $=90$, $\mathrm{p}<0.001)$.

\section{RESULTS}

The two species differed greatly in their levels of phenols: Pistacia had the highest concentrations (overall $2308 \pm 43 \mathrm{ppm}, \mathrm{n}=45$ ), with $J u$ niperus was quite a bit lower $(1516 \pm 43, \mathrm{n}=$ 45). Overall levels of phenols were highest in plants from the middle, and lowest in those from the bottom elevational level (figure 1). This effect of level was significant, showing that the two species showed the same pattern with elevation (Table 1). There were substantial differences among plots within levels (Table 1). The density of insect herbivores on $J u$ niperus was higher than that on Pistacia shrub, that possibly because of the low level of phenol in the Juniperus shrubs than in Pistacia shabbes: figure (2).

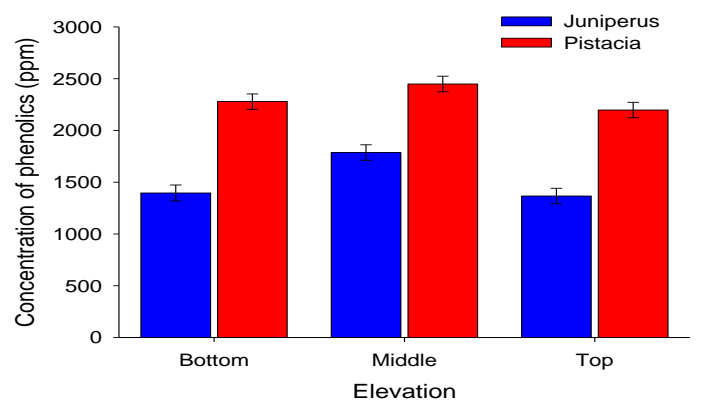

Figure 1:Phenolic content (parts per million) of leaves of Juniperus phoenicea and Pistacia atlantica shrubs/trees in the Al Jabal AlAkhdar region of Libya at three different elevational levels.

Table 1: Analysis of variation in the total phenolic content of Juniperus and Pistacia at three elevational levels in the Al Jabal Al Akhdar region of Libya.

\begin{tabular}{cccc}
\hline \hline \multirow{4}{*}{ Tests of Model Effects } \\
\cline { 2 - 4 } Source & \multicolumn{3}{c}{ Type } \\
\cline { 2 - 4 } & Wald Chi-Square & df & Sig. \\
\hline Species & 165.616 & 1 & .000 \\
Level & 21.924 & 2 & .000 \\
Plot(level) & 33.589 & 6 & .000 \\
Level * species & 2.371 & 2 & .306 \\
\hline \hline
\end{tabular}

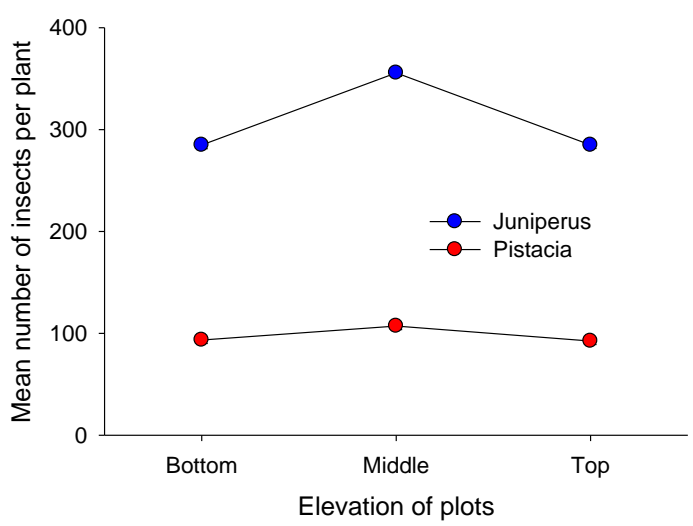

Figure 2: Average number ( \pm s.e.)of individual insects discovered on marked trees of Juniperus and Pistacia in permanent plots at three different elevations in the $\mathrm{Al}$ Jabal Al Akhdar study site. The standard errors are too small to be seen.

\section{DISCUSSION}

Our data suggest that phenol concentrations were consistently higher in Pistacia atlantica than in Juniperus phoenicea, over and above spatial variation, among and within elevations. Overall levels of phenols were highest in plants from the middle and lowest in those from the bottom elevational level. This effect of level was significant, but there was no species-level interaction, showing that the two species showed the same pattern with elevation. There were substantial differences among plots within levels, but no effect on plant volume. Alt- 
hough there may indeed be spatial and/or temporal differences in the defensive chemistry of plants in response to the risk of herbivory (Coley, Bryant, \& Chapin, 1985; Wold \& Marquis, 1997) attempts to document such effects in Mediterranean areas have not been very successful (Dement \& Mooney, 1974; Glyphis \& Puttick, 1988). (Avi Perevolotsky, 1994) could not find any seasonal or agerelated differences in the concentration of tannins in a variety of Mediterranean species, including Pistacia, Phillyrea, and Quercus. (Avi Perevolotsky, 1994) thought that constitutive were more likely in the Mediterranean than inducible defenses. Although our study was not designed explicitly to test this, we observed constancy of defense chemical differences for these two Mediterranean plants over a wide range of environmental conditions.

A vegetation of these plant communities usually consists of 20-25 shrub species in the Mediterranean region, but typically only six or seven species are dominant (Quercus ilex, Erica multiflora, Arbutus unedo, Juniperus phoeniceae, Viburnum tinus, Pistacia lentiscus, and Hedera helix) (Rogosic, Pfister, Provenza, \& Grbesa, 2006). However, utilization of the Mediterranean shrubs is often limited by secondary compounds such as tannins, terpenes, and saponins (A Perevolotsky et al., 1993).

Mediterranean woody evergreens are predicted to have strong primary (constitutive) defenses because, in contrast to deciduous woody plants, they keep more nutrients and carbon in their leaves. Herbivory is, therefore, more damaging to evergreens than to deciduous plants (Bryant et al., 1992; Herms \& Mattson, 1992). Several studies have shown that the leaves of Quercus spp. are high in phenolic compounds (Wold \& Marquis, 1997), and we found that Pistacia had even higher concentrations of phenolics than reported for Quercus, whilst Juniperus had much lower concentrations. Some studies seem to show that nitrogen content varies with season and leafage, but not among species
(Dement \& Mooney, 1974; Meletiou-Christou, Rhizopoulou, \& Diamantoglou, 1994). Concentrated study of the defense chemistry of Mediterranean plants is necessary before generalizations can be made.

The commonest species on Juniperus of sampling was Xylomeira sp. (Bostrichidae), a species that attacks live and dead wood. This might be a significant herbivore that could affect the survival and life-history of juniper in Al Jabal Al Akhdar. In fact, nearly all the commonest species on juniper were beetles including many wood-boring species, such as Agrilus (Xeragrilus) sp. (Buprestidae) and Purpuricenusdesfontainii (Cerambycidae). Clearly, juniper is a major resource for beetles in this area.

On Pistacia, on the other hand, the commonest species varied between years, with Orthoptera heading the list in the first sampling year: Paracinipe (Acinipe) orientalis, Oedopodacae rulescens, and Scintharistano tabilis. A set of wood-boring beetles were commonest in the second year of sampling, some of which were the same as those on juniper. This variability may indicate that the quality of Pistacia as a host varies among years, but we do not really have any real indication as to its basis.

Geography is clearly one of the major influences on the distribution of the insect herbivore fauna of Al Jabal Al Akhdar in the Mediterranean ecosystem. The number of recorded species broadly increases with elevation, while middle elevations had the greatest insect abundances. Insect damage to plants also increased with elevation, possibly due to a decrease in the number of Pistacia, which is observed in study area.

\section{CONCLUSION}

The study area is dominated by Juniperus $\mathrm{sp}$ and Pistacia sp, the two species selected for the study. Leaves were sampled for chemical analysis of their phenol (tannin) content. The re- 
sults showed that Tannin levels were much higher in Pistacia than in Juniperus, and there were effects of elevation as well. Plants from middle elevation plots had the highest levels, while those from the lowest elevation at the coast had the lowest levels of tannins. The density of insects on Juniperus sp was higher than that on Pistacia sp.

\section{ACKNOWLEDGMENT}

I would like to thank all those who stood with me for accomplishing this research and helped me materially and morally.

\section{REFERENCES}

Bryant, J. P., Heitkonig, I., Kuropat, P., \& Owen-Smith, N. (1991). Effects of severe defoliation on the long-term resistance to insect attack and on leaf chemistry in six woody species of the southern African savanna. The American Naturalist, 137(1), 50 .63-

Bryant, J. P., Reichardt, P. B., \& Clausen, T. (1992). Chemically mediated interactions between woody plants and browsing mammals. Rangeland Ecology \& Management/Journal of Range Management Archives, 45(1), 18-24 .

Coley, P. D., Bryant, J. P., \& Chapin, F. S. (1985). Resource availability and plant antiherbivore defense. Science, 230(4728), 895-899.

Dallman, P. R. (1998). Plant life in the world's Mediterranean climates: California, Chile, South Africa, Australia, and the Mediterranean basin: Univ of California Press.

Dement, W. A., \& Mooney, H. A. (1974). Seasonal variation in the production of tannins and cyanogenic glucosides in the chaparral shrub, Heteromeles arbutifolia. Oecologia, 15(1), 65-76 .

Faituri, M. Y. (2002). Soil organic matter in Mediterranean and Scandinavian forest ecosystems: Dynamics of organic matter, nutrients, and monomeric phenolic compounds .

Glyphis, J. P., \& Puttick, G. M. (1988). Phenolics in some southern African Mediterranean shrubland plants. Phytochemistry, 27(3), 7 .751-43

Herms, D. A., \& Mattson, W. J. (1992). The dilemma of plants: to grow or defend. The quarterly review of biology, 67(3), 283-335.

Levin, D. A. (1976). The chemical defenses of plants to pathogens and herbivores. Annual review of Ecology and Systematics, 7(1), 121-159.

Martinez, J.-J. I. (2002). Anti-insect effects of the gall wall of Baizongia pistaciae [L.], a gall-inducing aphid on Pistacia palaestina Boiss. Arthropod-Plant Interactions, 4(1), 29-34 .

Massei, G., Hartley, S. E., \& Bacon, P. J . .(2000). Chemical and morphological variation of Mediterranean woody evergreen species: Do plants respond to ungulate browsing? Journal of Vegetation Science, 11(1), 1-8 .

Meletiou-Christou, M., Rhizopoulou, S., \& Diamantoglou, S. (1994). Seasonal changes of carbohydrates, lipids and nitrogen content in sun and shade leaves from four Mediterranean evergreen sclerophylls. Environmental and Experimental Botany, 34(2), 129140 .

Muiruri, E. W., Barantal, S., Iason, G. R., Salminen, J. P., Perez - Fernandez, E ‘. 
\&Koricheva, J. (2019). Forest diversity effects on insect herbivores: do leaf traits matter? New Phytologist, 221(4), 2250-2260 .

Perevolotsky, A. (1994). Tannins in Mediterranean woodland species: lack of response to browsing and thinning. Oikos, 333 .340-

Perevolotsky, A., Brosh, A., Ehrlich, O., Gutman, M., Henkin, Z., \& Holzer, Z. (1993). Nutritional value of common oak (Quercus calliprinos) browse as fodder for goats: Experimental results in ecological perspective. Small Ruminant Research, 11(2). .106-95

Rogosic, J., Pfister, J. A., Provenza, F. D., \& Grbesa, D. (2006). Sheep and goat preference for and nutritional value of Mediterranean maquis shrubs. Small Ruminant Research, 64(1-2), 169-179 .

Rohner, C., \& Ward, D. (1997). Chemical and mechanical defense against herbivory in two sympatric species of desert Acacia. Journal of Vegetation Science, 8(5), 717-726.

Waterman, P. G., \& Mole, S. (1994). Analysis of phenolic plant metabolites (Vol. 83): Blackwell Scientific Oxford.

Wold, E. N., \& Marquis, R. J. (1997). Induced defense in white oak: effects on herbivores and consequences for the plant. Ecology, 78(5), 1356-1369 . 
الدفاعات الفينولية في شجيرتي العرعر والبطوم ضد العاشبات الحشرية في منطقة الجبل الأخضر-ليبيا

$$
\text { عبد الرحمن يوسف الفيتوري }
$$

قسم وقاية النبات، كلية الززارعة، جامعة عر المختار، البيضاء، ليبيا.

تاريخ الاستلام: 18 فبراير 2019 / تاريخ القبول: 30 يونيو 2019 https://doi.org/10.54172/mjsc.v34i2.83 Doi

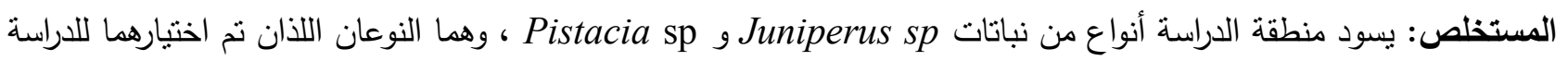

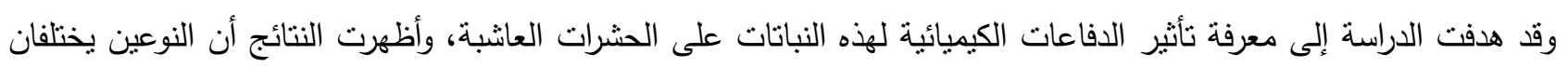

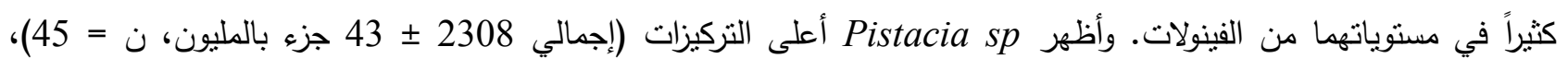

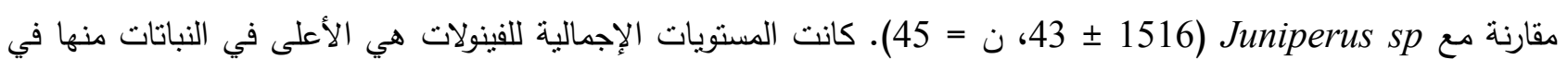

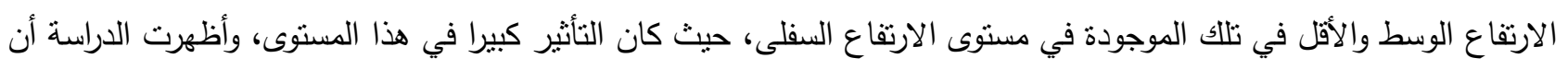

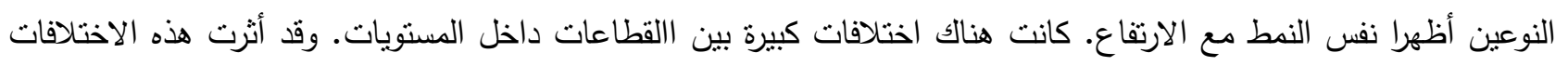

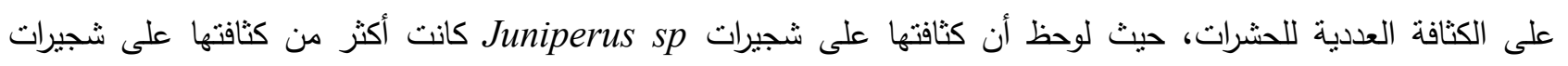
.Pistacia $s p$

الكلمات المفتاحية: الدفاعات الفينولية؛ العرعر والبطوم؛ الحشرات العانبة؛ الجبل الأخضر ، ليبيا. 